\title{
ANALISIS KEPUTUSAN PEMBERIAN KREDIT MODAL KERJA TERHADAP USAHA KECIL MENENGAH (Study Kasus Pada PD BPR Bank Daerah Lamongan)
}

\author{
Sutri Handayani \\ Fakultas Ekonomi, Universitas Islam Lamongan \\ sutrihandayani99@gmail.com
}

\begin{abstract}
ABSTRAK
Penelitian ini bertujuan untuk menganalisis antara faktor-faktor nilai jaminan, omset usaha/penjualan, umur usaha, jumlah tanggungan keluarga dalam mempengaruhi keputusan pemberian kredit modal kerja Study Kasus PD BPR Bank Daerah Lamongan. Metode yang digunakan dalam penelitian ini adalah analisis regresi logistik dan dilanjutkan dengan pengujian statistik untuk mengetahui seberapa besar pengaruh empat variabel dependen terhadap variabel independen.

Hasil pengujian hipotesis secara simultan dan parsial menunjukkan bahwa variabel nilai jaminan, omset usaha, umur usaha berpengaruh positif terhadap keputusan pemberian kredit modal kerja, sedangkan jumlah tanggungan keluarga tidak berpengaruh negatif terhadap keputusan pemberian kredit modal kerja. Hasil penelitian umur usaha memiliki koefisien regresi yang terbesar 3,683 dengan signifikansi terkecil 0,055. Hal ini menunjukkan bahwa umur usaha calon debitur menjadi pertimbangan tertinggi dalam pengambilan keputusan pembelian kredit pada PD BPR Bank Daerah Lamongan.
\end{abstract}

Kata Kunci : Kredit Modal Kerja, Usaha Kecil Menengah

\section{PENDAHULUAN}

Bank adalah lembaga keuangan yang sangat dibutuhkan oleh masyarakat dengan tingkatan sosial dan ekonomi yang beragam. Dalam kondisi demikian pentinglah kita lebih mengenal perbankan, seperti dasardasar dan sistem perbankan yang sah dan karena tidak semua lembaga keuangan disebut bank, dan tidak semua yang mengatas namakan bank dinyatakan sebagai bank yang sah menurut undang-undang yang berlaku. Menurut Undang-Undang No. 10 tahun 1998, bank adalah badan usaha yang menghimpun dana dari masyarakat dalam bentuk simpanan dan menyalurkan kepada masyarakat dalam bentuk kredit atau bentukbentuk lainnya dalam rangka meningkatkan taraf hidup rakyat banyak.

Sebagaimana umumnya negara berkembang, sumber pembiayaan dunia usaha masih didominasi oleh penyaluran kredit. Penyaluran kredit memungkinkan masyarakat untuk 
melakukan investasi, distribusi, dan juga konsumsi barang jasa, mengingat kegiatan investasi, distribusi dan komsumsi adalah kegiatan pembangunan ekonomi masyarakat.

Kredit merupakan salah satu sumber permodalan yang sangat memiliki peran besar dalam kegiatan usaha. UKM adalah skala bisnis yang memerlukan kredit sebagai pertambahan permodalan dalam menjalankan dan mengembangkan usahanya, dan Perbankan adalah lembaga keuangan yang mengeluarkan kredit.

Sehingga kredit atau pinjaman merupakan kegiatan yang menghasilkan keuntungan dan laba rugi bank. Tidak hanya bank yang mendapatkan keuntungan dari kegiatan kredit atau pinjaman, akan tetapi sektor UKM juga mendapatkan keuntungan, karena kredit atau pinjaman merupakan salah satu faktor penting dalam menunjang kegiatan UKM.

Menurut Kasmir (2012) jaminan kredit suatu perjanjian antara kreditur dengan debitur, dimana debitur menjanjikan sejumlah hartanya untuk kepentingan pelunasan utang apabila pada waktu yang telah ditentukan terjadi kemacetan atau gagal bayar terhadap utangnya. Penilaian jaminan dilakukan oleh bank untuk memperoleh nilai dari suatu aset atau properti yang akan dijadikan jaminan kredit. Hasil dari penilaian ini kemudian dijadikan acuan oleh bank dalam memberikan batas jumlah kredit yang akan diberikan kepada nasabah.

Menurut Anwar (2013) umur usaha yaitu lamanya usaha berdiri dan berkembang dan bertahan. Umur usaha dihitung sejak perusahaan itu berdiri, berdasarkan akta pendirian. Perusahaan yang sudah lama berdiri kemungkinan sudah banyak pengalaman yang diperolehnya. Semakin lama umur perusahaan, semakin banyak informasi yang telah diperolah masyarakat tentang perusahaan tersebut. Sehingga dapat disimpulkan umur usaha mempengaruhi kredit.

Menurut Arinda (2015) omset usaha merupakan pendapatan kotor yang diterima rata-rata perbulannya. Omset usaha yang semakin tinggi menunjukkan kapabilitas usaha yang semakin baik dalam mengelola usaha, sehingga kemampuan untuk membayar kredit maka akan semakin meningkat.

Menurut Sulis (2011) jumlah tanggungan keluarga yaitu jumlah tanggungan debitur termasuk istri atau 
suami, anak kandung serta saudara lainnya yang masih tinggal dalam satu rumah dan masih dalam tanggungan debitur diukur dengan jumlah orang. Semakin banyak anggota yang ditanggung oleh debitur membuat kebutuhan dalam keluarga semakin banyak. Sehingga pendapatan yang diperoleh debitur harus dialokasikan untuk kebutuhan yang diprioritaskan dalam keluarga. Hal ini membuat debitur kesulitan untuk mengembalikan kredit dalam jangka waktu tertentu.

Berdasarkan urian latar belakang masalah diatas maka bermaksud untuk melakukan penelitian yang berjudul "Analisis Keputusan Pemberian Kredit Modal Kerja Terhadap Usaha Kecil dan Menengah (Studi Kasus pada PD BPR Bank Daerah Lamongan)".

\section{TINJAUAN PUSTAKA}

\subsection{Modal Kerja}

Kredit modal kerja adalah fasilitas kredit yang digunakan untuk membiayai.

Dalam pemberian kredit modal kerja terdapat prinsip-prinsip meliputi :

1. Character (watak) : faktor utama dalam memutuskan pemberian kredit.

2. Capacity (kemampuan) : Mengukur tingkat kemampuan debitur dalam mengembalikan kredit dari usaha yang dibiayai mencakup aspek manajemen, produksi, pemasaran, personalia dan finansial.

3. Capital (Modal) : mengukur kemampuan debitur dalam menyediakan modal sendiri.

4. Collateral (Jaminan) : menentukan nilai pasar wajar dari jaminan yang akan diikat sebagai jaminan.

5. Codotion of economy (Kondisi Ekonomi) : mengetahui prospektif atau tidaknya suatu usaha yang akan dibiayai.

\subsection{Pendapatan}

Pendapatan merupakan faktor utama dimana kita mampu mengetahui suatu perusahaan mengalami perkembangan dalam usahanya atau mengalami penurunan dalam usahanya, karena pendapatan merupakan unsur dari sebuah laporan keuangan khususnya laporan L/R. 


\section{METODE PENELITIAN}

Analisis data adalah kegiatan mengolah data yang telah dikumpulkan dari lapangan atau perpustakaan yang menjadi seperangkat hasil yang terbaik dalam bentuk penemuan baru maupun dalam pembentukan hipotesis. Setelah data terkumpul, maka langkah selanjutnya adalah menganalisis datadata tersebut sehingga mempunyai makna untuk mengungkapkan berbagai masalah yang ada. Metode analisis data yang digunakan adalah penelitian kuantitatif dengan menggunakan analisis regresi logistic, Binary logistik regression adalah variabel dependennya berskala dikotomi (dua pilihan) misalnya $\mathrm{y}=1$ diterima atau $\mathrm{y}$ $=0$ di tolak.

Tujuan dari analisis ini adalah untuk mengetahui besarnya pengaruh masing-masing variabel bebas terhadap variabel terikatnya. Variabel yang di ukur dalam penelitian ini adalah Analisis Nilai Agunan, Umur Usaha, Omset Usaha, Jumlah Tanggungan Keluarga atau variabel bebas (X) dengan Keputusan Pemberian Kredit Modal Kerja sebagai (Dependent Variable) variabel terikat (Y).

\section{Statistik Deskriftif}

Statistik deskriptif memberikan gambaran atau deskripsi suatu data yang dilihat dari nilai rata-rata (mean), median, modus, standar deviasi, maksimum dan minimum. Statistik deskriptif merupakan statistik yang menggambarkan atau mendeskripsikan data menjadi sebuah informasi yang lebih jelas dan mudah untuk dipahami.

\section{Analisis Regresi Logistik}

Analisis yang digunakan dalam penelitian ini adalah analisis regresi logistik (logistic regression), yaitu dengan melihat pengaruh nilai agunan, umur usaha, omset usaha, dan jumlah tanggunan keluarga terhadap keputusan pemberian kredit oleh BPR Bank Daerah Lamongan. Adapun model regresi dalam penelitian ini adalah sebagai berikut:

$\mathbf{E}(\mathbf{Y} \mid \mathbf{X})$

$$
=\frac{\mathrm{e}^{\beta_{0}+\beta_{1} X_{1}+\beta_{2} X_{2}+\beta_{3} X_{3}+\beta_{4} X_{4}}}{1+\mathrm{e}^{\beta_{0}+\beta_{1} X_{1}+\beta_{2} X_{2}+\beta_{3} X_{3}+\beta_{4} X_{4}}}
$$

Keterangan : 
$\mathrm{E}(\mathrm{Y} \mid \mathrm{X})=\quad$ Peluang keputusan pemberian kredit diterima

$\beta_{0} \quad=$ Konstanta

$\beta_{1}-\beta_{5}=$ Koefisien regresi

$X_{1}=$ Nilai jaminan

$X_{2}=$ Umur usaha

$X_{3} \quad=$ Omset usaha

$X_{4}=$ Jumlah Tanggungan

Keluarga

\section{Pengujian Hipotesis Menilai} keseluruhan model

Pengujian dilakukan dengan membandingkan nilai antara -2 log likelihood pada awal (blok number $=0)$ dengan nilai -2 log likelihood pada akhir (blok number =1). Pengurangan nilai antara -2LL awal (initial -2LL function) dengan nilai $-2 L L$ pada langkah awal berikutnya menunjukkan bahwa variabel yang dihipotesiskan fit dengan data. Hal ini karena $\log$ likelihood pada regresi logistik mirip dengan "sum of square error" pada model regresi sehingga penurunan log likelihood menunjukkan model regresi semakin baik.

4. Pengujian Hipotesis Uji Kelayakan Model Regresi

Kelayakan model regresi ditentukan berdasarkan nilai dari Hosmer \& Lemeshow's Goodness of Fit Test. Jika nilai statistik Hosmer \& Lemeshow's Fit Test lebih besar dari 0,10 maka hipotesis nol tidak dapat ditolak yang berarti model mampu memprediksi nilai observasinya atau dapat dikatakan model dapat diterima karena sesuai dengan data observasinya.

\section{Menguji koefisien regresi}

Pengujian ini dilakukan untuk mengetahui apakah masingmasing variabel independen berpengaruh terhadap variabel dependen dengan menggunakan Wald statistic dan nilai probabilitas. 


\section{PEMBAHASAN}

a. Statistik Deskriftif

Digunakan mengetahuai rata-rata ( Mean. Maksimum, Minimum, Standart umur usaha, omset usaha, jumlah tanggungan keluarga Adapun hasil perhitungan IBM SPSS terlihat pada tabel

Deviasi) dari variabel nilai agununa,

Tabel 1. Statistik Deskriptif

\begin{tabular}{|l|l|l|l|l|l|}
\hline & N & \multicolumn{1}{|c|}{ Min } & \multicolumn{1}{|c|}{ Maks } & \multicolumn{1}{|c|}{ Mean } & \multicolumn{1}{|c|}{ Std. Deviation } \\
\hline Nilai agunan & 30 & 9.500 .000 & 200.000 .000 & $79.616 .666,67$ & $55.859 .226,28$ \\
Omset usaha/penjualan & 30 & 28.728 .730 & 1.709 .748 .74 & $379.356 .918,2$ & $372.516 .246,1$ \\
Umur usaha & 30 & 1,5 & 3 & 2,100 & 0,4624 \\
Jumlah tanggungan keluarga & 30 & 3 & 2,5 & 4,17 & 1,053 \\
Valid N (listwise) & 30 & & 6 & & \\
& & & & & \\
\hline
\end{tabular}

Sumber : Hasil Olah Data Sekunder SPSS 20

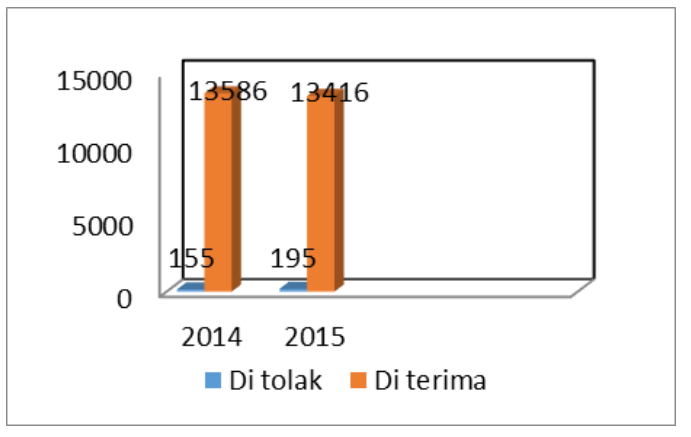

Gambar 1. Kredit yang ditolak dan diterima tahun 2014-2015

\section{b. Analisis Regresi Logistik}

Model regresi logistik yang terbentuk dari hasil analisis sebagai berikut ;
Tabel 2. Koefisien Regresi Logistik

\begin{tabular}{|l|c|c|c|}
\hline Variabel & Koefisien & Signifikansi & $\begin{array}{c}\text { Odds } \\
\text { Ratio }\end{array}$ \\
\hline Nilai agunan & 0,000 & 0,074 & 1,198 \\
\hline Omset Usaha & 0,000 & 0,091 & 2,864 \\
\hline Umur Usaha & $-11,485$ & 0,055 & 3,683 \\
\hline $\begin{array}{l}\text { Jumlah } \\
\text { Tanggungan } \\
\text { Keluarga }\end{array}$ & 1,613 & 0,245 & 1,352 \\
\hline Konstanta & 10,404 & 0,096 & 2,777 \\
\hline
\end{tabular}

Sumber : Hasil Olah Data SPSS 20

\section{Hasil pengujian koefisien} regresi logistik berdasarkan tabel diatas menghasilkan sebuah model sebagai berikut ; 
$E(Y \mid X)$

$=\frac{e^{10,404+0,000 \mathrm{X} 1+0,000 \mathrm{X} 2-11,485 \mathrm{X} 3+1,613 \mathrm{X} 4}}{1+e^{10,404+0,000 \mathrm{X} 1+0,000 \mathrm{X} 2-11,485 \mathrm{X} 3+1,613 \mathrm{X} 4}}$

Nilai odds ratio dari nilai jaminan sebesar 1,198 menunjukkan kemungkinan diterimanya pengajuan kredit seseorang yang memiliki nilai jaminan 1 rupiah lebih besar yaitu sebesar 1,198 kali daripada seseorang yang memiliki nilai jaminan 1 rupiah lebih rendah. Hal ini menunjukkan bahwa semakin tinggi nilai jaminan yang diberikan oleh calon debitur sebagai jaminan kredit, maka semakin besar pula peluang permohonan kredit yang akan disetujui.

Nilai odds ratio omset usaha sebesar 2,864 hasil tersebut menunujukkan bahwa kemungkinan diterimanya pengajuan kredit seseorang yang memiliki omset usaha 2 rupiah lebih besar yaitu 2,864 kali daripada seseorang yang memiliki omset usaha sebesar 2 rupiah lebih rendah. Semakin besar omset usaha yang dihasilkan oleh debitur, maka peluang kredit yang akan diterima akan lebih besar.

Nilai odds ratio umur usaha sebesar 3,683 hasil tersebut menunjukkan bahwa kemungkinan atau risiko diterimanya pengajuan kredit seseorang yang memiliki umur usaha 3 tahun lebih besar yaitu sebesar 3,683 kali daripada seseorang yang memiliki umur usaha 3 tahun lebih rendah. Umur usaha dijadikan salah satu faktor dari keputusan pemberian kredit oleh pihak bank, dikarenakan umur usaha yang lama menandakan manajemen perusahaan atau kinerja usaha yang dimiliki debitur dapat berjalan dengan baik, selain itu usaha yang lama menunjukkan bahwa usaha tersebut memiliki manajemen pengelelolaan yang baik.

Nilai odds ratio jumlah tanggungan keluarga sebesar 1,352 hasil tersebut menunujukkan bahwa kemungkinan diterimanya pengajuan kredit seseorang yang memiliki omset usaha 1 rupiah lebih besar yaitu 1,352 kali daripada seseorang yang memiliki omset usaha sebesar 1 rupiah lebih rendah. Besar kecilnya jumlah tanggungan keluarga biasanya diasumsikan menjadi salah satu faktor yang mempengaruhi keputusan pemberian kredit. 
c. Pengujian Hipotesis Menilai keseluruhan model

Tabel 3. Hasil Uji -2 Likelihood Iteration History

\begin{tabular}{|l|c|}
\hline$-2 \log$ likelihood awal (Block Number 0) & 38,191 \\
\hline$-2 \log$ likelihood akhir (Block number 1) & 9,843 \\
\hline
\end{tabular}

Sumber ; Hasil Olah Data SPSS 20

Berdasarkan tabel diatas pengujian pada blok 0 atau pengujian dengan tidak memasukkan seluruh prediktor diperoleh nilai -2 likelihood sebesar 38,191. Nilai tersebut tidak mengalami penurunan rendah yang menunjukkan sebagai model yang belum dapat menjelaskan hubungan variabel bebas dan variabel terikatnya.

Sedangkan block 1 pada diperoleh nilai -2 log likelihood sebesar 9,843. Hal ini menunjukkan bahwa terjadi penurunan $-2 \quad \log$ likelihood yang cukup besar jika dibandingkan dengan nilai -2 log likelihood block 0 . Hal ini menunjukkan bahwa ada hubungan antara variabel bebas dengan variabel terikatnya. Dengan nilai -2 log likelihood value block number $=$ 0 lebih besar dari -2 log likelihood value number $=1$ maka model regresi ini semakin layak atau baik.

\section{d. Pengujian Hipotesis Uji} Kelayakan Model Regresi

Tabel 4. Hosmer and Lemeshow Test

\begin{tabular}{|l|c|}
\hline \multicolumn{1}{|c|}{ Keterangan } & Hasil \\
\hline Chi-square & 1,775 \\
\hline Df & 8 \\
\hline Sig & 0,987 \\
\hline
\end{tabular}

Sumber ; Hasil Olah Data SPSS 20

Berdasarkan tabel diatas model regresi dalam penelitian ini ditunjukkan dalam menggunakan Hosmer And Lemeshow's Goodness Of Fit Test. Hasil dari Hosmer And Lemeshow's Goodness Of Fit Test menunjukkan Chi-square sebesar 1,775 dengan signifikan 0,987 . Berdasarkan hasil tersebut menunjukan bahwa nilai signifikasi diatas 0,10 yang berarti hipotesis nol $\left(H_{0}\right)$ diterima, sehingga model tersebut mampu memprediksi nilai observasinya. Kemudian untuk nilai Chi-square table untuk df 8 pada taraf sinifikansi 0, 10 sebesar 20.090 sehingga nilai Chi-square hitung $(1,775)$ lebih kecil dari Chi-square table menunjukkan bahwa model dapat diterima dan pengujian hipotesisnya dapat dilakukan. 


\section{e. Menguji Koefisien Regresi}

a. Uji hipotesis secara simultan

Dalam pengujian regresi logistik, untuk melihat uji signifikan simultan dapat dilihat dari penurunan nilai $\quad-2 \quad \log$ likelihood yang disajikan dalam tabel 6 omnimus test of model coefficients diperoleh dengan nilai chi square 28,348 dengan nilai signifikan sebesar 0,000 . Dengan tingkat signifikan yang lebih kecil dari 0,10 maka dapat disimpulkan bahwa secara bersama-sama keempat variabel independen penelitian; nilai agunan, omset usaha, umur usaha, jumlah tanggungan keluarga berpengaruh terhadap keputusan pemberian kredit modal kerja.

Tabel 5. Omnibus Tests of Model Coefficients

\begin{tabular}{|cc|c|c|c|}
\hline & & $\begin{array}{c}\text { Chi- } \\
\text { square }\end{array}$ & Df & Sig \\
\hline Step 1 & Step & 28,348 & 4 & 0,000 \\
& Block & 28,348 & 4 & 0,000 \\
Model & 28,348 & 4 & 0,000 \\
& & & \\
\multicolumn{3}{|r|}{ Sumber ; Hasil Olah Data SPSS 20 }
\end{tabular}

b. Uji hipotesis parsial

Berdasarkan tabel 2 diatas maka dapat diperoleh hasil untuk menguji signifikan dari masing-masing variabel independen, pembahasan hasil pengujian secara parsial untuk masing-masing variabel independen tersebut adalah sebagai berikut :

1. Nilai Agunan

Berdasarkan hasil pengujian hipotesis menunjukkan nilai signifikansi nilai agunan sebesar 0,074 dibawah $10 \%$ sehingga hasil tersebut menyatakan bahwa nilai agunan berpengaruh terhadap keputusan pemberian kredit modal kerja. Hasil penelitian menerima hipotesis $1\left(H_{1}\right)$ yang menyatakan bahwa nilai agunan berpengaruh terhadap keputusan pemberian kredit modal kerja.

2. Omset Usaha

Berdasarkan hasil pengujian hipotesis menunjukkan nilai 
signifikansi umur usaha sebesar 0,055 dibawah $10 \%$ sehingga hasil tersebut menyatakan bahwa umur usaha berpengaruh terhadap keputusan pemberian kredit modal kerja. Hasil penelitian menerima hipotesis $2\left(\mathrm{H}_{2}\right)$ yang menyatakan bahwa omset usaha/penjualan berpengaruh terhadap keputusan pemberian kredit modal kerja.

3. Umur Usaha

Berdasarkan hasil pengujian hipotesis menunjukkan nilai signifikansi omset usaha sebesar 0,091 dibawah $10 \%$ sehingga hasil tersebut menyatakan bahwa omset usaha berpengaruh terhadap keputusan pemberian kredit modal kerja. Hasil penelitian menerima hipotesis $3\left(\mathrm{H}_{3}\right)$ yang menyatakan bahwa umur usaha berpengaruh terhadap keputusan pemberian kredit modal kerja.

4. Jumlah Tanggungan Keluarga
Berdasarkan hasil pengujian hipotesis menunjukkan nilai signifikansi jumlah tanggungan keluarga sebesar 0,245 diatas $10 \%$ sehingga hasil tersebut menyatakan bahwa jumlah tanggungan keluarga tidak berpengaruh terhadap keputusan pemberian kredit modal kerja. Hasil penelitian menolak hipotesis $4 \quad\left(H_{4}\right)$ yang menyatakan bahwa jumlah tanggungan keluarga berpengaruh terhadap keputusan pemberian kredit modal kerja.

\section{f. Analisis Hasil Penelitian}

a. Pengaruh secara simultan Tabel 6. Model Summary

\begin{tabular}{|c|c|}
\hline $\begin{array}{c}\text { Cox \& Snell R } \\
\text { Square }\end{array}$ & 0,611 \\
\hline $\begin{array}{c}\text { Nagelkerke R } \\
\text { Square }\end{array}$ & 0,849 \\
\hline \multicolumn{2}{|c|}{ Sumber ; Hasil Olah Data SPSS 20 }
\end{tabular}

Berdasarkan tabel 6 diatas Nilai Cox \& Snell R Square dan Nagelkerke $R$ Square mempunyai definisi yang sama dengan $\mathrm{R}$ Square yaitu 
menunjukkan pengaruh secara bersama-sama. Besarnya nilai determinasi dalam model ditunjukkan oleh nilai Nagelkerke R Square yang lebih besar daripada nilai Cox \& Snell $\mathrm{R}$ Square dalam model ini adalah 0,849 atau 84,9\% yang baerarti bahwa pengaruh variabel dependen dapat dijelaskan dengan variabel independen nilai agunan, omset usaha, umur usaha, jumlah tanggungan keluarga sebesar $84,9 \%$ sedangkan sisanya 15,1 $\%$ dijelaskan dalam variabel lain yang tidak termasuk dalam model regresi.

b. Pengaruh secara parsial

1. Pengaruh Nilai Agunan (Jaminan Kredit) terhadap Keputusan Pemberian Kredit Modal Kerja

Pengujian pengaruh variabel nilai agunan terhadap keputusan pembeerian kredit modal kerja didasarkan pada nilai odds ratio sebesar 1,198 dengan nilai signifikan 0,074. Dengan nilai signifikan yang dibawah 10
$\%$ maka hasil ini menunjukkan bahwa nilai agunan berpengaruh tehadap keputusan pemberian kredit modal kerja pada usaha kecil menengah. Hal ini menunjukkan bahwa semakin tinggi nilai jaminan yang diberikan oleh calon debitur sebagai jaminan kredit, maka semakin besar pula peluang permohonan kredit yang akan disetujui.

Hasil penelitian ini sesuai dengan teori yang dikemukakan oleh Novitasari (2015) dan Hardinata (2014) bahwa nilai jaminan berkaitan erat dengan pemberian kredit, karena jaminan kredit berfungsi sebagai menjamin pelunasan kredit ketika debitur mengalami gagal bayar. Oleh karena itu pentingnya nilai jaminan ini untuk mengamankan dana bank yang disalurkan sebagai kredit.

$$
\begin{array}{r}
\mathrm{H}_{1}: \text { Nilai Agunan } \\
\text { Berpengaruh Positif } \\
\text { terhadap Keputusan }
\end{array}
$$


Pemberian Kredit

Modal Kerja.

2. Pengaruh Omset Usaha/ Penjualan terhadap Keputusan Pemberian Kredit Modal Kerja.

Pengujian pengaruh variabel omset usaha terhadap keputusan pemberian kredit modal kerja didasarkan pada nilai odds ratio sebesar 2,864 dengan nilai signifikan 0,091. Dengan nilai signifikan yang dibawah 10 $\%$, maka hasil ini menunjukkan bahwa omset usaha berpengaruh tehadap keputusan pemberian kredit modal kerja pada usaha kecil menengah. Semakin besar omset usaha maka semakin besar produktifitas yang dijalankan. Hal ini berarti menunjukkan hubungan baik dalam mengelola usaha. Ketika produktifitas semakin besar maka laba usaha yang diterima nasabah juga akan semakin besar.

Hasil penelitian ini juga mendukung penelitian yang dilakukan oleh Hardinata (2014) dimana omset usaha memiliki pengaruh terhadap keputusan pemberian kredit. $\mathrm{H}_{2}$ : Omset Usaha Berpengaruh Positif terhadap Keputusan Pemberian Kredit Modal Kerja.

3. Pengaruh Umur Usaha terhadap Keputusan Pemberian Kredit Modal Kerja

Pengujian pengaruh variabel umur usaha terhadap keputusan pemberian kredit modal kerja didasarkan pada nilai odds ratio sebesar 3,683 dengan nilai signifikan 0,055. Dengan nilai signifikan yang dibawah 10 $\%$, maka hasil ini menunjukkan bahwa umur usaha berpengaruh tehadap keputusan pemberian kredit modal kerja pada usaha kecil menengah. Umur usaha dijadikan salah satu faktor dari keputusan pemberian kredit oleh pihak bank, 
dikarenakan umur usaha yang lama menandakan manajemen perusahaan atau kinerja usaha yang dimiliki debitur dapat berjalan dengan baik, selain itu usaha yang lama menunjukkan bahwa usaha tersebut memiliki manajemen pengelelolaan yang baik. Hal inilah yang menjadikan umur usaha sebagai salah satu faktor yang digunakan pihak bank dalam keputusan pemberian kredit.

Hasil penelitian ini sejalan dengan Novitasari (2015) yang mengatakan bahwa umur usaha berkaitan erat dengan keputusan pemberian kredit karena umur usaha yang semakin lama menandakan manajemen usaha yang baik.

\section{$\mathrm{H}_{3}$ : Umur Usaha} Berpengaruh Positif terhadap Keputusan Pemberian Kredit Modal Kerja.

4. Pengaruh Jumlah Tanggungan Keluarga terhadap Keputusan
Pemberian Kredit Modal Kerja

Pengujian pengaruh variabel Jumlah Tanggungan Keluarga terhadap keputusan pemberian kredit modal kerja didasarkan pada nilai odds ratio sebesar 1,352 dengan nilai signifikan 0,245. Dengan nilai signifikan yang diatas $10 \%$, maka hasil ini menunjukkan bahwa jumlah tanggungan keluarga tidak berpengaruh tehadap keputusan pemberian kredit modal kerja pada usaha kecil menengah.

Hasil penelitian ini tidak sejalan dengan penelitian yang dilakukan Arinda (2015). Secara asumtif bila dilihat jumlah tanggungan keluarga menentukan pengeluaran dari debitur itu sendiri, ketika tanggungan keluarganya besar maka pengeluaran debitur untuk kebutuhan semakin besar. Besar kecilnya jumlah tanggungan keluarga 


\begin{tabular}{lrlr} 
biasanya & diasumsikan & \multicolumn{1}{l}{ digunakan } & $\begin{array}{l}\text { untuk } \\
\text { menjadi salah satu faktor }\end{array}$ \\
yang & mempengaruhi & kengeluaran & kebutuhan \\
keputusan pemberian kredit. & ini digunakan untuk \\
Namun & berdasarkan & perkembangan usaha. \\
penelitian ini menunjukkan & $\mathbf{H}_{\mathbf{4}}:$ Jumlah Tanggungan \\
bahwa jumlah tanggungan & Keluarga \\
keluarga tidak berpengaruh & Berpengaruh Positif \\
terhadap & keputusan & terhadapKeputusan \\
pemberian kredit. Dimana & Pemberian Kredit \\
jumlah tanggungan keluarga & Modal Kerja.
\end{tabular}

tidak terlalu memiliki pengaruh yang terhadap keputusan pemberian kredit. Jumlah tanggungan keluarga yang kecil akan memiliki risiko yang sama dengan debitur yang memiliki jumlah tanggungan yang besar. Dengan kata lain berapapun jumlah tanggungan keluarga dari debitur tidak menentukan kemampuan debitur dalam melunasi utangnya. Jumlah tanggungan keluarga yang tidak berpengaruh signifikan ini juga dikarenakan kredit yang diberikan dalam penelitian ini merupakan kredit modal kerja, oleh karena itu kredit ini tidak

\section{PENUTUP}

\subsection{Simpulan}

Berdasarkan hasil penelitian variabel nilai agunan, omset usaha, umur usaha berpengaruh positif keputusan pemberian kredit modal kerja di PD BPR Bank Daerah Lamongan. Karena ke 3 variabel tersebut mempunyai nilai signifikan diatas $10 \%$ sehingga hasil menyatakan bahwa berpengaruh positif terhadap keputusan pemberian kredit modal kerja. Sedangkan jumlah tanggungan keluarga tidak berpengaruh terhadap keputusan pemberian kredit modal kerja. Karena jumlah tanggungan keluarga mempunyai nilai signifikan di atas $10 \%$ sehingga berpengaruh negatif.

Berdasarkan hasil penelitian variabel umur usaha dilihat dari nilai 
odds ratio paling besar 3,683 dari ke 3 variabel independen; nilai agunan odds rationya 1,198 , omset usaha odds ratio 2,864, jumlah tanggungan keluarga odds ratio 1,352. Hasil tersebut menunjukkan bahwa umur usaha merupakan variabel yang paling berpengaruh positif terhadap keputusan pemberian kredit modal kerja.

\subsection{Saran}

1. Bagi Nasabah

a. Dalam mengajukan permohonan kredit modal kerja, sebaiknya nasabah melengkapi seluruh persyaratan yang telah ditetapkan oleh pihak bank tanpa terkercuali.

b. Data-data yang diserahkan kepada pihak bank harus sesuai dengan kondisi yang sebenarnya, seperti laporan

Keluarga dalam memberikan keputusan kredit modal kerja.

3. Bagi Peneliti Selanjutnya

a. Penelitian selanjutnya diharapkan untuk mengkaji lebih banyak sumber maupun referensi yang terkait dengan keputusan kredit modal kerja keuangan harus sesuai dengan kondisi usaha yang dijalankan.

c. Dalam memberikan jaminan kepada pihak bank, jaminan harus bebas dari berbagai macam masalah dan nilai jaminan harus dapat menutup jumlah kredit yang diajukan

2. Bagi Bank

a. Dalam memberikan keputusan kredit kepada calon debitur, bank harus lebih teliti dalam melakukan analisis kredit dengan selalu menerapkan prinsip 5C (Character, Capacity, Capital, Condition of Economic, dan Collateral) dari calon debitur.

b. Berdasarkan penelitian yang dilakukan, bank harus lebih menilai variabel jaminan, omset usaha, dan umur usaha, jumlah tanggungan

agar penelitiannya dapat lebih baik dan lebih lengkap.

b. Penelitian selanjutnya diharapkan lebih mempersiapkan diri dalam proses pengambilan dan pengumpulan dan segala sesuatunya sehingga penelitian 
ini dapat dilaksanakan dengan

lebih baik.

c. Peneliti selanjutnya diharapkan ditunjang pula dengan wawancara dengan sumber yang berkompeten dalam kajian modal kerja.

\section{DAFTAR PUSTAKA}

Anwar, Hasan, 2013.Pengaruh Aset, Keuntungan, Lama Usaha, Presepsi Tingkat Suku Bunga dan Jenis Kelamin, Pendidikan dan Usia terhadap Keputusan UKMK Mengambil Kredit Perbankan (Studi Kasus, Kabupaten Kudus).Skripsi. Semarang: Universitas Diponegoro .

Arinda, Nila, 2015. Analisis Pengaruh Usia, Jumlah Tanggungan Keluarga, Pengalaman Usaha, Omset Usaha dan Jumlah Pinjaman Terhadap Pengembalian Kredit UKM (Study Kasus, Bank Pengkreditan Rakyat Gunung Rinngit Malang). Skripsi. Malang : Universitas Brawijaya.

Adi Purnomo, Gede. 2012. Keputusan Pemberian Kredit Modal Kerja Perusahaan Jasa Pada PT Perusahaan Bali Cabang Singaraja. Skripsi. Universitas Pembangunan Nasional 'Veteran'.

Cholifah, 2015. Analisis Pemberian Kredit Terhadap Pendapatan Pedagang Kecil (Studi Kasus, pada BMT Mandiri Sejahtera
Kec. Karanggeneng Kabupaten lamongan).Skripsi.Lamongan: Unversitas Islam Lamongan.

Enggar Jati, Disca Suci, 2015. Pengaruh Pemberian Kredit Modal Kerja Terhadap Pendapatan Usaha Kecil Menengah pada PT Bank Pembiayaan(Bprs) Bahagia Bantul.Skripsi. Yogjakarta : Universitas Sunan Kalijaga.

Firdausi, M. 2010. Faktor-Faktor Yang Mempengaruhi Keputusan Dalam Pemberian Kredit Invetasi Oleh PT. PR Surya Artha Utama Surabaya. Skripsi.UPN.

Hardinata, Yusvendy, 2014. Analisis Keputusan Pemberian Kredit Modal Kerja Terhadap Usaha Kecil Menenengah (Study Kasus, pada Bank BRI KCP Malang).Jurnal Universitas Brawijaya.

Irham, Fahmi. 2010. Pengantar Manajemen Pengkreditan, Anggota Ikatan Penerbit Indonesia (IKAPI).

Kasmir. 2014. Manajemen Perbankan., PT. Grafindo Persada.

Kasmir. 2012. Bank Dan Lembaga Keuangan Lainya, PT. Grafindo Persada.

Nitisusastro, Mulyadi, 2012. Kewirausahaan dan Manajemen Usaha Kecil Menengah. Alfabeta, Bandung.

Novitasari, Aderma.2015. Analisis Pengambilan Keputusan Pemberian Kredit Modal Kerja(Studi pada Bank Bri Kantor Cabang Martadinata 
Malang). Jurnal Universitas Brawijaya.

Pernama Wati, Nirwayana, 2014. Pengaruh Pemberian Kredit Modal Kerja Terhadap Pendapatan UKM. Jurnal Bisma Universitas Pendidikan Ganesha. Volume 2.
Republik Indonesia.1998.Undang- Undang No.10 Tentang Perbankan.

Sugiono. 2014. Metode Penelitian Kuantitatif Kualitatif dan $R \& D$, Anggota Ikatan Penerbit Indonesia (IKAPI).

Wahyono, Teguh. 2012. Analisis Statistic Mudah Dengan SPSS 20. PT Elex Media Komputindo. 